Robert Dittmann

Academy of Sciences of the Czech Republic

\title{
Czech Reformational biblical translation: the case of pericopes in the Unity of the Brethren in the 1550s-1570s
}

\section{Introduction: the Bohemian Reformation and Czech language in the High Middle Ages}

The Bohemian Reformation is a specific phenomenon in the late medieval Europe $^{1}$. For the first time in the Roman obedience, there asserted a split into Utraquists and minority Catholics, which makes Hussitism the first successfully established reform movement in the West [Šmahel 2001: 431]. The experience of the duality of two equal Christian faiths was legally confirmed by the Kutná Hora Treaty of 1485 - for the first time in European history [Válka 2005: 242], and primacy holds also Jiří of Poděbrady's idea of an association of European Christian monarchs living one beside the other in peace. At the same time, the Hussite tradition "remained largely restricted to Czech-speaking areas" [Šmahel 2016: 9]. Therefore the Bohemian Reformation acquired very soon a nationalistic colouring, which reflected itself also in the language: soon after 1415, Czech was promoted among the radical Hussitic currents to the lingua sacra, the language of liturgy - an achievement utterly exceptional among living languages in the sphere of Roman obedience. Thus the efforts to eradicate Hussitism were perceived as attempts at "physical liquidation of the Czech "tongue" and it was concluded that the "interests of the faith are identical with the interests of the Czech 'tongue"', as the period pamphlets put it [both quotes

1 This study is a result of the research funded by the Czech Science Foundation as the project GA ČR P401/12/G168 "History and Interpretation of the Bible" and carried out at the Institute of Philosophy of the Academy of Sciences of the Czech Republic in Prague. Transcription rules for Czech are taken over from the edition Bible kralická šestidilná. Kompletni vydání s pưvodními poznámkami [2015], but we modify capitalization and punctuation (also, we do not add quotation marks in the transcription). 
from Šmahel 2014: 79; the Old Czech word jazyk meant both 'language' and 'nation', see Šimek 2019].

The Czech language in the High Middle Ages had a unique position among Slavic tongues. Having reached the solely position of the only fully developed and unified standard living Slavonic language [Havránek 1936: 44], the Czech of the 14th and 15th centuries bequeathed us more than one hundred thousand words, gathered now in dictionaries of Old Czech, the total of almost thirty manuscripts of the complete Old Czech bibles and the Czech influence radiated abroad, especially into medieval Poland.

The pericopes had been a subject of disputes on Czech soil for a long time. Not only were they one of the problematic issues in Great Moravia in the 9th century, they appear also as the last direct evidence of the Slavic liturgy with eastern rite in the Jagić Glosses of the early 12th century. In them, the glossed passages correspond to pericopes of a compact part of the liturgical year. The Prague reform movement starting in the latter half of the 14th century is closely related to the reading of pericopes in Old Czech: already Matěj of Janov is said to have introduced reading of the epistle and gospel in $\mathrm{Czech}^{2}$ and the demand of these two readings in the vernacular recurred in the Hussite claims and became one of the typical features of the Czech Utraquist mass. Indeed, an index of pericopes is generally the most typical appendix to Czech biblical manuscript translations, these indices are included in fifty-four manuscripts from the 15th century alone [Svobodová, Voleková (forthcoming)].

\section{The Unity of the Brethren}

Whereas the Hussitic radicalism gradually waned and faded away, one radical sectarian community emerging in the late 1450 s separated from the mainstream Utraquism about a decade later: the Unity of the Brethren. This was the inheritor proper [Šmahel 2014: 84] of the radical Taborite ideas including the total orientation towards the Czech language in the mass. This community, repeatedly banned and prosecuted yet slowly growing in some respects and regions, remained illegal until the Letter of Majesty issued by Rudolph II in 1609 and would be prohibited again from the 1620s onwards. The Unity of the Brethren is the most suitable object for exploring confessional identity in the Bohemian Lands [cf. Vykypělová 2013: 240]. This is due to its separeteness, vitality and autonomy. Unlike the Utraquists, the Unity "broke entirely from the Catholic Church, and in doing so became the first independent church in the European

2 Holeton [1993: 158]; cf. Holeton [2016] and Dittmann [2018] on the general overview and further references. 
Reformation" [Šmahel 2016: 12]. Dogmatically, the Unity was an original Czech product of the Reformation and till the end of its existence on the Bohemian soil, it protected carefully its peculiarity and independence in the disputes and contacts with other Reformational currents, Catholicism and Utraquism. It started as a national, Czech-oriented church, and although it succeeded in attracting some German-speaking believers and spread to the Polish-Lithuanian Commonwealth or Upper Hungary, it retained for a relatively long time its basically Czech character. It was also a Bohemian church with the first exile experiences gained as a consequence to the 1547 estate uprising.

The Unity treasured its specificity by a number of tractates defending its teachings and attacking its opponents. Its uniqueness is also visible in a particular development of theology and book production. Actually, it not only completed the process of confessionalization first [Vykypělová 2013: 240] but was also the only confession to issue its own complete confessionally clearly shaped translation of the New Testament and the whole Bible in the pre-1620 Czech lands. The Unity's distinctiveness was reflected, among other things, in the language they used and its orthography. Despite being a small community, initially with sectarian features, it gradually attracted more and more believers, but even at the end of the 16th century it gained only about forty thousand adherents in Bohemia and Moravia. They were located prevailingly in Moravia (an estimate of 24.000 believers), in Bohemia they counted only around 16.000. This makes less than $3 \%$ of the then population in Moravia and less than $1 \%$ in Bohemia [cf. Bůžek et al. 2010: 104; Just 2009: 11].

\section{Pericopes in the Unity}

Following the radical Hussitic currents, the Unity was totally oriented to the Czech language as Josef Macek [2001: 302] put it. It refused Latin in mass liturgy. In the first decades of its existence, the system of pericopes in the Unity was not stabilized and the preacher chose an arbitrary pericope or a motif for the sermon [Landová 2014: 122]. It was only Lukáš Pražský, the most important Brethren theologian, who at the beginning of the 16th century returned to the generally used system of pericopes of the Roman Church [Landová 2014: 123]. Both New Testaments, connected somehow to the Brethren and printed in Mladá Boleslav in 1518 and 1525 respectively, use this old system. Especially in the 1525 New Testament and pericopes attached to the print, Lukáš Pražský applied the principle of word-for-word translation and revived the outdated synthetic past tense called the imperfect, e.g. in a pericope from $\mathrm{Da} 14$ we read imperfects bieše, dáváchu, biechu,jdieše, sediše. This translation is based strictly on the Vulgate and is the most literal one among all 16th-century Czech 
New Testaments. Lukáš includes several kinds of harsh Latinisms such as participle constructions, possessive and comparative genitives, subjunctive for Latin conjunctive in dependent clauses, historical present tense, and possessive pronouns distributed as in Latin.

\subsection{Augusta's attempt at a new system of pericopes}

Nevertheless, a departure from Lukáś's teachings in the Unity after his death in 1528 affected also the pericopes and their system. Whereas Lutherans never dared to leave the old system of pericopes, shared with the Roman Church [Landová 2014: 125], the Unity gradually started to test a new system. In the second half of the 1540s, a novel system based on the Apostolic Creed was given a try in some congregations. The initiator of this system was Bishop Jan Augusta, Lukáš's successor and pupil. He did not stop working on this system even during his long-term internment in the 1550s. In 1555 or soon after he finished his manuscript book Register [cf. Landová 2014: 124-129]. This unpreserved translation of pericopes was based quite literally on Biblia Tigurina, a Zurich Reformational translation of Leo Jud and his colleagues, published in 1543 and 1544 . We think so because a later printed version of the pericopes, Augusta's Summovnik (published around 1570), has this rather literal translation of the Biblia Tigurina, which Augusta provably used during his internment [cf. Dittmann 2017]. Let us give here only a few previously unnoticed illustrative examples of textual differences, i.e. textual pluses, minuses and different interpretations, excerpted from the printed version of the Summovnik (shortened hereafter as Sum) agreeing with the Tigurina (shortened as Tig) in comparison with the Clementine Vulgate (Vg) and the Netolický Bible of 1549 (BiblNet). They are extracted from pericopes Mt 4:1-4; Lk 18:31-43; J 1:1-14; J 19:16-30, Tt 2:11-14; Heb 1:1-2:1.

a) Textual pluses include: Heb 1:3 Sum zretedlný obraz (Tig expressa imago) - Vg figura (BiblNet obrazem); Heb 1:3 Sum skrze sebe samého (Tig per semetipsum) - Vg omitted (BiblNet omitted). Even bracketed translators' additions of the Tigurina are reflected in the Summovník: J 1:8.9 Sum ale (poslán byl) aby (Tig sed [missus erat] ut) - Vg sed ut (BiblNet ale aby). The translation is rather literal, therefore demonstrative pronouns are often copied such as in J 1:1 Sum to Slovo (Tig illud verbum) - Vg verbum (BiblNet Slovo); J 1:8 Sum o tom světle (Tig de luce illa) - Vg de lumine (BiblNet o světlu); J 1:8.9 Sum světlo to (Tig lux illa) - Vg lux (BiblNet světlo).

b) Textual minuses include e.g. omissions of demonstratives such as J 1:9 Sum na svět (Tig in mundum) - Vg in hunc mundum (BiblNet na tento svět). 
c) Different interpretations include: J 19:23 Sum když ukřižovali Ježišse (Tig quum crucifixissent Iesum) - Vg cum crucifixissent eum (BiblNet když jsou jej ukřižovali); Tt 2:11 Sum spasitedlná (Tig salutifera) - Vg Salvatoris nostri (BiblNet spasitele našeho); Tt 2:11 Sum zasvitila se (Tig illuxit, marginal note: Al. [= Alii] apparuit) - Vg apparuit (BiblNet okázala se); Tt 2:14 Sum lid zvláštní (Tig populum peculiarem) - Vg populum acceptabilem (BiblNet lid vzácný); Heb 1:12 Sum svineš je (Tig circumvolves eos) - Vg mutabis eos (BiblNet změníš je); Heb 2:1 Sum kteréž jsou nám praveny (Tig quae dicta sunt nobis) - Vg quae audivimus (BiblNet což jsme slýchali). Even slight differences are transferred into the Summovník such as a shift in a grammatical category or a preposition: Heb 1:6 Sum na okršlek zemí (Tig in orbem terrarum) - Vg in orbem terrae (BiblNet na okršlek zemé); Heb 1:7 Sum o anjelích (Tig de angelis) - Vg ad angelos (BiblNet $k$ andělům); Heb 1:11 Sum zůstáváš (Tig permanes) - Vg permanebis (BiblNet zuostaneš). In some cases, the difference lies in the participle versus finite verb competition: Mt 4:3 Sum když pak přistoupil (Tig cumque accessisset) - Vg et accedens (BiblNet a pristúpiv); Mt 4:4 Sum slovem vycházejícím (Tig verbo egrediente) - Vg verbo, quod procedit (BiblNet slovem, kteréž pocházi); J 1:12 Sum věrícím totiž (Tig credentibus scilicet) - Vg his qui credunt (BiblNet těm, kteřřz věři).

However, Augusta's translation of pericopes never gained any official approval of the Unity. The Summovnik was printed as a private and personal initiative of Augusta and its printing was probably stopped, so that only a part of the work has been published [on details see Landová 2014: 122-146; Just 2017]. Nevertheless, its place in the history of pericopes on the Czech soil is quite important: for the first time, the Old Testament pericopes acquired primarily a non-Vulgate basis, despite mediated by a Latin humanistic translation of the Tigurina. Even though the Swiss translation was "admired for its pleasing style" [Gordon - Cameron 2016: 207], Augusta's Czech translation turned the opposite, due to disturbing and harsh Latinisms.

\subsection{The undated Registrum aneb Zpráva [...] (probably 1557-1559)}

Augusta's manuscript translation from 1555 was smuggled out of his internment to the other leaders of the Unity. After some corrections, the pericopes were printed probably between the years 1557-1559 under the title Registrum aneb Zpráva $[\ldots]^{3}$. The print itself, preserved incompletely, is undated. The editorial work and corrections were done by Bishop Jan Černý, whom two other bishops, Jan Blahoslav and Matěj Červenka, probably helped or were at

3 On the print and its background see Bat'ová [2013]. 
hand. In comparison with the printed Summovnik the text displays modifications and inclines in some places to the Vulgate, since there appear agreements with the Czech tradition based on the Vulgate, e.g. the Netolický Bible of 1549 [cf. Landová 2012: 349]. Also, agreements with Brethren prints of the 1560s have been identified, namely with Blahoslav's New Testament (printed for the first time in 1564) and Červenka's Psalter (1562) [Landová 2014: 136]. Despite a deeper philological analysis has been missing, it may be safely stated that the text of the Registrum aneb Zpráva [...] is a textual mixture consisting of readings identical with the Vulgate and non-Vulgate tradition with some readings unparalleled in the preceding Czech translation tradition at all [cf. Landová 2012: 350]. The degree and translatological and editorial strategy may vary as we shall demonstrate on two randomly selected examples from the New Testament pericopes.

First, the pericope $\mathrm{J}$ 6:1-14 is a fairly faithful copy of the mainstream Czech tradition as represented among other prints by the Netolický Bible of 1549 , including literal and precise copying of its word order, whereas lexical differences are limited to substitution of the relative pronoun který for jenž only, attested four times. However, two places are especially noteworthy: for J 6:11 BiblNet rozdával sedicim (Vg distribuit discumbentibus), the Registrum reads rozdal učedlníkům. Učedlníci pak sedícím (cf. Sum rozdělil učedlníkuom, učedlníci pak posazeným and Tig distribuit discipulis, discipuli vero discum-

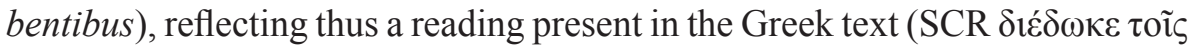

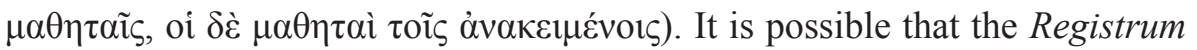
took this reading over from the Melantrich Bible of 1556-1557 which for the first time in Czech tradition among whole bibles reads rozdával učedlnikuom, učedlnici pak sedicim (the Náměšt’ New Testament of 1533, based on Latin Erasmus' version, translates rozdal učedlníkom, učedlnici pak stolícím where stolicim renders Erasmus' discumbentibus [cf. Brown, ed. 2001: 68]). The Melantrich Bible of 1556-1557 may have served as the immediate model for the Registrum as it did later for Blahoslav's New Testament of 1564. The latter place is J 6:14 where the Registrum reads Ježišs, an equivalent present in the Sum, Vg and Tig, but the Netolický Bible and the Melantrich Bible of 1556-1557 both omit it. It is important to note that Blahoslav's New Testament translation differs in the respective passage to a small degree from the version in the Netolický Bible (BiblNet) and the Melantrich Bible of 1556-1557 (BiblMel2) and from Registrum and Summovnik, namely by a more careful respecting the Greek version in the case of participles, cf. J 6:5 Reg, Sum, BiblNet pozdvihl ... viděl (Vg sublevasset ... vidisset, Tig sustulisset ... vid-

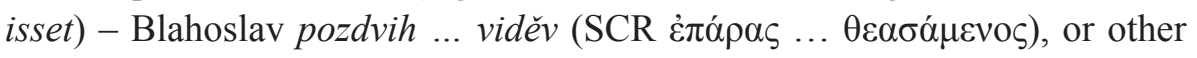


readings such as J 6:2 Reg nad těmi, jenž nemocní byli, Sum nad těmi, kteřiž nemocni byli, BiblNet nad těmi, kteřiž nemocní byli (Vg, Tig super his qui

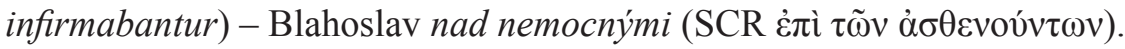

On the contrary, a pericope from the beginning of the New Testament Mt 11:2-15 shows a higher resemblance in the Registrum to the Summovnik version than the former pericope analysed above, cf. Mt 11:2 Reg uslyšel v žaláři o skutcích Krystových, vyslav dva z učedlníkưv svých - Sum uslyšel v žaláři skutky Krystovy, poslav dva z učedlnikuov svých - BiblNet, BiblMel2 uslyšal v okovách skutky Krystovy, poslav dva učedlniky svá; Mt 11:3 Reg, Sum přijiti

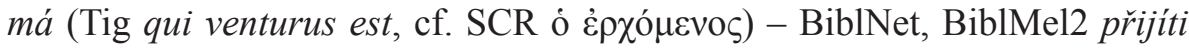
máš (Vg venturus es); Mt 11:3-4 Reg čili jiného čekati máme? A odpověděv

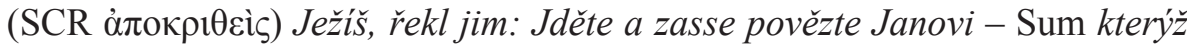
přijíti má, čili jiného čekáme? A odpovidaje Ježíš, řekl jim: Jděte a zvěstujte zas Janovi (Tig qui venturus est, an alterum expectamus? Et respondens Iesus, dixit illis: Ite, \& renunciate Ioanni) - BiblNet čtení svaté, BiblMel2 čili jiného čekáme? I odpovídaje Ježí̌́, řekl jim: Jdúce pověztež Janovi (Vg an alium exspectamus? Et respondens Jesus ait illis: Euntes renuntiate Joanni), Mt 11:5 Reg veselé poselství evanjelium - Sum veselé zvěstování evangelium (Tig

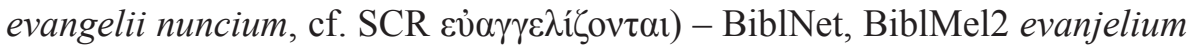
svaté (Vg evangelizantur), Mt 11:12 Reg, Sum chvátají- BiblNet, BiblMel2 uchvacujit', Mt 11:14 Reg, Sum přijíti - BiblNet čtení svaté, BiblMel2 chcete-li rozuméti etc. However, also in this pericope there occurs a strong relation to the Netolický and Melantrich Bible versions, since some of Augusta's literal translations must have sounded as improper Czech to the Brethren editors of the Registrum. Other readings are shared by Summovnik, Registrum and Blahoslav's New Testaments of 1564 and 1568 (e.g. Mt 11:3 čekati máme, marginal note čekáme, cf. SCR $\pi \rho \circ \sigma \delta о \kappa \tilde{\omega} \mu \varepsilon v ;$ Mt 11:14 prijíti), although the latter's translations show rather obvious closeness to the Melantrich Bible tradition. In the pericope under examination a typical feature may be noticed in the Registrum, namely occurrence of a Czech past transgressive at a place where the Greek text displays a participle of the aorist (Mt 11:4 odpověděv cf. Blahoslav in, J 6:5 pozdvih, viděv). This would become the most typical feature of Blahoslav's revision of the traditional Czech New Testament text [Kyas et al. 1997: 180]. Whether the differences in editorial attitudes to J 6 and Mt 11 might indicate anything about the progress of Blahoslav's own translation of New Testament, only future scholarship may specify.

Another co-editor of the Registrum, Matěj Červenka, published in 1562 a translation of the Psalter. Agreements with this translation have been found in the Registrum [Landová 2014: 136]. Let us add here some more examples: 
as a matter of fact, Psalm 1 in the Registrum shows in our view a number of agreements which are singular for these two translations, among them $v$ sňátku posměvačův, u stoku, se zvede, roznáší, neostojí, v zboru svatých, stezka bezbožnikưv, on the contrary the translation departs significantly from the Summovnik and also shows disagreement with the Melantrich tradition. Probable Červenka's presence and Blahoslav's absence in redaction of this psalm may be suggested from translations such as štastně se zvede (Ps 1), psové and zprobodali (both Ps 22), readings criticized explicitly in Blahoslav's grammar [Čejka, Šlosar, Nechutová, eds. 1991: fols. 334a, 337a]. In comparison with the Registrum, Červenka prefers the lexeme Hospodin for earlier Pán, otherwise the translation in most verses of Psalm 1 literally agrees with the Registrum:

Sum: Blahoslavený jest ten muž, kterýž ani v radu bezbožných všel, ani na cestě hříšníkův stál, ani v stolicech posměvačův seděl. Ale v zákoně Páně vůle jeho jest. A v zákoně jeho přemyšlovati bude dnem i nocí. Tent' bude tak jako strom štípený podlé potočných vod, kterýž ovotce své vydává časem svým; jehožto list nespadá, a cožkoli vydal by, k prospěchu přijde. Ne tak bezbožní jsou, ale tak jako plévy, kteréž rozptyluje vítr. Tou př́ícinou nevyvstanou bezbožní na soudu ani hříšníci v zástupu spravedlivých. Nebo zná cestu spravedlivých, cesta pak bezbožných zahyne.

Reg and Červenka ${ }^{4}$ : Blahoslavený jest ten muž (ČER Blahoslavený muž), kterýž neodšel po radě bezbožníkův a na cestě hříšníkův nestál (ČER neustrnul) a v sňátku posměvačův se neusadil. Ale v zákoně Páně jest vůle jeho (ČER Ale v zákoně Hospodina líbost má) a v zákoně jeho přemejšleti bude dnem i nocí (ČER dnem i nocí přemejšlí). Ten bude (ČER Tent’ jest) jako dřevo, kteréž štípeno jest u stoku řek, ješto ovoce své vydává časem svým, jehožto list nespadá, a všecko, cožkoli činiti bude, št'astně se zvede. Ne tak bezbožní, ale budout' (ČER jsút') jakožto prach, kterýž roznáší vítr. Protož neostojí bezbožní v soudu ani hř́šníci v zboru svatých. Nebot' zná Pán (ČER Hospodin) cestu spravedlivých, a stezka bezbožníkův zahyne.

There are several more passages from Psalms among the pericopes in the Registrum, among them Ps 22:2-23; 41:1-14; 91:1-16; 109:1-31; 110:1-6; 119:86-120, this selection being excerpted by us from a list compiled by

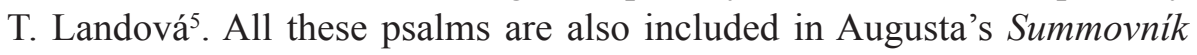

4 We neglect purely orthographical and small phonetical and phonological changes such as uo/ $\mathrm{u}$ interchanges.

5 Landová [2014: 350-360]. Augusta's Summovnik contains of this selection the following pericopes: Ps 22, 41, 91, 110, 119 (the latter with a different length). 
(the Ps 119 pericope differs in length). Also among these pericopes we find numerous obvious singular agreements between the Registrum and Červenka's Psalter, whereas the Summovnik chooses a different translation. Among such examples we may list rozdirají usta svá (Ps 22:8), ukřivuji (Ps 22:8), zčechře (Ps 41:4), zlé mi vinšuji (Ps 41:6), kdy aspoň umře (Ps 41:6, cf. Sum když pak umře), bubli proti mně (Ps 41:8), červík ... utržka lidská a povrhel (Ps 22:7; Červenka reads outržka), od moru nejlitějšího (Ps 91:3), pod křidly jeho doufáni míti budeš (Ps 91:4), náhlého zhoubce poledního (Ps 91:6; cf. Sum: zhoubce poledniho), vysvobodím jej, ochráním a zastru jej (Ps 91:14), nebude ... toho žel (Ps 110:4), naplní těly zbitých (Ps 110:6), rtom ... ustom ... soudom (Ps 119:103.108), kochání míti budu (Ps 119:117), and there occurs a high degree of agreement in some verses such as Ps 41:7 Přijde-li kdo z nich, aby mne navštívil, neupřimě mluví v srdci svém, nahromáždil sobě hřichưv, a vyjda ven, toliko pomluvy strojí (Registrum), where Červenka's version does not differ lexically from the Registrum at all ${ }^{6}$, and similarly in Ps 91:14-16 the Registrum version - apart from the conjuction $a$ and a non-independent particle - $t$ ' - is lexically fully identical with Červenka whereas Augusta's Summovnik again deviates considerably. As a result, we may conclude that there can be no doubt about a strong mutual relation between the Registrum and Červenka's Psalter in most of the psalms mentioned, with one exception: the translations of Ps 109:1-31 in the Registrum and Cervenka differ remarkably. This fully confirms previous findings of Eliška Bat'ová who searched out the textual source for this psalm in a previous writing by Augusta dated to the first half of the 1540s [Bat'ová 2013: 209]. At the same time, the translation of Ps 109 displays more elegant Czech than Červenka's Psalter, since there do not appear such marked renderings as rozčesla and obežvali present in the latter's version. If the dating of the Registrum to the years of 1557-1559 is correct, one may conclude that at least parts of Červenka's Psalter must have been in preparation or in manuscript already by then or that Červenka's editorial alterations were to be largely accepted in his later published Psalter, whereas the Summovnik translation was not used as the textual basis for the Registrum in these passages. This conclusion is in line with Eliška Bat'ová's [2013: 209] analysis of Psalms 16 and 26: she found out that readings identical with Červenka's Psalter prevail, but there are also readings shared with the Melantrich Bible and some readings are unique, and some of the latter would emerge again in Stefan's postil of 1575 . The Registrum shares the numbering of psalms with the Vulgate tradition [Bat'ová 2013: 209].

6 Augusta's Summovnik reads differently: A kdožkoli z nich přišel mne navštíviti, marné věci mluvil, srdcem křivé věci sobě zbiral, vejda ven, vypravoval je. 
Other Old Testament pericopes - the sample for the puropse of analysis in this article included Is 7:10-16, Is 11:1-10, Is 60:1-14 and Mal 3:1-5 show approximation in the Registrum to the Vulgate readings in some cases [cf. Landová 2012: 349]. For instance in Is 7:14 the Summovník reads nazoveš ... Immanu El (Tig vocabis ... Immanu El) whereas the Registrum reads dáno bude jméno Emanuel (Vg vocabitur nomen ... Emmanuel), in Is 60:1 it adds Jeruzaléme in agreement with the Vulgate whereas the Summovnik and Tigurina omit it, in Is 60:7 it returns to the Vulgate proper noun reading by the form Nabajotští (Vg Nabaioth) whereas the Summovnik reads Nebaiot in agreement with the Tigurina (Nebaioth) ${ }^{7}$. On the other hand, there occur also departures from the Vulgate, hinted at already by Eliška Bat'ová [2013], and approximations to the Hebrew text, mediated by a Latin translation, which is reflected in proper nouns, for example Is 11:1 Izay (Sum Jesse, Vg and Tig Iesse, BiblMel2 Jesse, but the Hebrew text reads Jišaj), and other readings such as Is 60:7 dìm slávy (Sum duom velebnosti, Tig domum magnificentiae, in margine gloriae, Vg domum maiestatis, BiblMel2 duom velebnosti). Such a reading (domum gloriae) occurs not only in the margin of the Biblia Tigurina but unsurprisingly in some of the sources for its marginalia [cf. Gordon, Cameron 2016: 206], namely in Sebastian Münster's translation of Old Testament, issued in 1534-1535, and Pagninus' translation, which appeared for the first time in 1528. The latter occurred also in Stephanus' edition of 1556-1557, both editions could have been at Blahoslav's disposal [cf. Dittmann 2012: 106, 108; Just 2007: 120-122]. The relation between the Summovnik and the Registrum may be supported by interchange of the marginal note (ditě, kteréž prsí poživá) and the main text (ssanec) of the Summovnik in the Registrum which reads only ditě, kteréž prsí poživá (Is 11:8; cf. BiblMel2 ditě od prsí, Vg infans ab ubere). A deeper and more systematic analysis of the Registrum still remains, however, a desideratum for a future elaborate research.

\subsection{Blahoslav's Evanjelia of 1571 and Štefan's postil of $\mathbf{1 5 7 5}$}

The debates in the Unity of the Brethren about pericopes did not cease after 1559. A new compromise between the old system of pericopes and Augusta's innovative suggestion as realized in the Summovnik and accepted with some modifications by the Registrum was assembled in the early 1560 s by Bishop Jan Černý, whose version was corrected by bishops Matěj Červenka and Jan Blahoslav. The print was issued in 1563 yet regretfully no surviving copies have been discovered [cf. Landová 2014: 133-142]. However, we may suppose

7 For examples from Isaiah see Dittmann [2018: 131-132, 2017: 66-68]. 
that the Old Testament textual version of this print was taken over by two later prints of the 1570s which include pericopal readings: Blahoslav's Evanjelia (1571) and Štefan's postil (1575). In New Testament pericopes these prints of the 1570s unsurprisingly utilized the latest Brethren approved translation of Jan Blahoslav's New Testament of 1568. In the Old Testament, however, there was none such a new complete translation, since Červenka's Psalter (1562) was probably a merely private initiative [Just 2016: 64] and its language was sternly criticized by Blahoslav. It has been shown that the Old Testament pericopes of the Evanjelia (1571) and Stefan's postil (1575) share the identical translation, which displays a certain degree of non-Vulgate readings [Dittmann 2012: 177-178], namely in the case of pericopes Is 9:2-7, Is 11:1-10, Mi 5:2-4. Here we may add that also in the case of the only remaining Old Testament pericope in the Evanjelia present in Štefan's postil, namely Is 59:20-60:14, the translation there takes over the version of the Evanjelia completely, with only minute differences: Is 59:21 and 60:9 Evanjelia s nimi versus Štefan's postil $s$ nimi, Is 60:6.10.12 neb-nebo and vice versa, Is 60:6 velbloudiv - velbloudio, Is 60:6 př́idou-prijdou, Is 60:11 nebudout'-nebudou. We showed elsewhere [Dittmann 2016: 250-254] that in Štefan's postil there emerge numerous nonVulgate readings alongside the Vulgate-based ones and that some readings penetrated into following Brethren prints such as the Kralice Psalter of 1579 and the Six-Volume Kralice Bible.

Now we may add comparisons of the recently identified Registrum (1557-59) and Štefan's postil (1575), which will be based on randomly selected passages Gn 2:18-24, 4:1-16, 2S 7:1-17, Ps 1:1-6, 91:1-16; 110:1-7, Mal 3:1-5, of which none is included in the Evanjelia, and furthermore Is 59:20-60:14, Mi 5:2-4, present also in the Evanjelia.

Let us start with the passages present also in the Evanjelia. Since we concluded above that the Evanjelia version was fully taken over by Štefan's postil, the statements concerning textual relationships between the Registrum and Štefan's postil will be valid also for relationships between the Registrum and the Evanjelia. First, it is important to confirm Eliška Bat'ová's [2014: 244] findings that the textual version of the Registrum (Reg) is clearly reflected in the Evanjelia (and therefore Štefan's postil, we may add, as well). She compared pericopes Is 9:2-7, Is 11:1-10, Is 52:1-10, Is 59:20-60:14, Is 66:5-14, Mi 5:2-4 from Evanjelia with the Registrum and concluded that the Evanjelia show a high degree of textual agreement, some parts of the Registrum being taken over literally, others being, however, significantly modified.

Indeed, a comparison of the beginning of the pericope of Is 60:1-14 from the Registrum and the corresponding versets of Štefan's postil undoubtedly shows 
a direct dependence of the latter on the Registrum [cf. Bat'ová 2014: 244]. Differences in the Registrum are typed in italics, disrespected are two word order changes commented below:

Reg: Povstaniž tehdy a zastkvějž se, ó Jeruzaléme, nebt' jest přišlo světlo tvé a sláva Páně vzešla jest nad tebou. Neb aj, tmy přikryjí zemi a mrákota lidi, ale nad tebout'vzejde Pán a sláva jeho ukáže se na tobě. Pohané budou choditi v světle tvém a králové v blesku nad tebou vzešlém. Pozdvíhniž očí svých vůkol sebe a popatř. Tito všickni hromadně $\mathrm{k}$ tobě poberou se a synové tvojí zdaleka prrijdou. Dcery pak tvé po boku tvém vychovány budou.

ŠtefPost: Povstaniž tedy a zastkvěj se, ó Jeruzaléme, nebt’ jest přišlo světlo tvé a sláva Páně vzešla jest nad tebou. Neb aj, tmy přikryjí zemi a mrákota lidi, ale nad tebou vzejdet' Hospodin a sláva jeho se ukáže na tobě. Pohané budou choditi v světle tvém a králové v blesku nad tebou vzešlém. Pozdvihniž očí svých vůkol sebe a popatř, tito všickni $\mathrm{k}$ tobě hromadně poberou se a synové tvoji zdaleka prrijdou; dcery pak tvé po boku tvém vychovány budou.

The versions differ only in minute details in vowel quantity (pozdvíhniž/ pozdvihniž, tvoji/tvoji), varying forms (such as tehdy/tedy), emphatic particles $-\check{z},-t$ ' and two slight word order shifts (ukáže se > se ukáže, hromadně k tobě > $k$ tobě hromadně). There appears one terminological substitution Pán > Hospodin, but the two versions represent certainly one translation basis. In other parts of this pericope, however, the translation of the Registrum was deeply revised [cf. Bat'ová 2014: 244] ${ }^{8}$, with some readings in line with the Vulgate (e.g. Is 60:6 nesouce ... vzdávajice) and others with non-Vulgate sources (e.g. Is 60:9 lodi tarsenské) [Dittmann 2018: 132]. Since we do not possess the 1563 edition, we cannot determine with certainty whether the textual modification in the 1570 s simply equals to the 1563 version - a possibility supported by the system of pericopes in Štefan's postil [Bat'ová 2012: 42] - or represents another revision [cf. Bat'ová 2014: 244].

On the contrary, the pericopal passages from Gn 2 (Gn 2:1-25 in Reg, Gn 2:18-24 in ŠtefPost), Gn 4:1-16 and 2S 7:1-17 in Štefan's postil are translated anew and independently, with new readings departing from the Vulgate to the non-Vulgate tradition such as Gn 2:18 Reg učiňmež (Vg faciamus) ŠtefPost učiním, Gn 2:20 Adam (Vg Adam) - člověk, Gn 2:21 na Adama (Vg in

8 We thus confirm Eliška Bat'ová's [2014: 244] findings on a close relationship between Registrum and Blahoslav's Evanjelia in some pasaages, since the Evanjelia and Štefan's postil have virtually identical text. Bat'ová suggests that the differences may have been consequences of Jan Blahoslav's own revision. 
Adam) - na člověka. The same direction is followed by shifts in Gn 4:8 vyjděma ven - omitted, Gn 4:16 vyhnaný na zemi (Vg profugus in terra) - v zemi Nod, and 2S 7:2 omission as in the Vulgate - král.

Moreover, it seems that in Psalms the version preserved in Štefan's postil goes back generally to the Registrum version, and it certainly does not take over the version of Červenka's Psalter mechanically as one might expect, cf. Ps 91:4 Reg, ŠtefPost křidly svými přikryje tě versus Červenka brky svejmi přikryje tě, Ps 91:13 po lvu versus po štíru ksenčím, Ps 110:2 panúj(ž) versus aby panoval, Ps 110:3 ve dni vítězství tvého /Reg vítěstvíl versus ve dni vítězného taženi tvého, Ps 110:6 souditi bude versus soudy pomst svých uvede), even though some readings are closer to the latter. These comprise, for example, Ps 110:1 na pravici and nepodložím (Reg po pravici, nepoložím), Ps 110:6 povýší (Červenka povejši; Reg pozdvihne), in Ps 1:2 přemejšli (a form criticized by Blahoslav, whereas another such form zvede is substituted by povede, a lexeme recommended by him). Mutual dependence of the three texts is further proved by the marginal reading potre in Štefan's postil in Ps 110:6, which is attested in both Registrum and Červenka. There appear, however, no returns to the version recorded in the Summovnik in Ps 110, whereas there are possible cases of inspiration by and/or restoration of the Summovnik readings in Ps 1, cf. Ps 1:1 Sum $v$ stolicech, ŠtefPost na stolici - Reg, Červenka $v$ sňátku; Ps 1:4 Sum plévy, ŠtefPost plevy - Reg, Červenka prach; Ps 1:5 spravedlivých-svatých). It is nevertheless apparent that reception of Červenka's translation was rather reserved in the Unity in comparison with the warm welcome enjoyed by Blahoslav's New Testament translation, republished in 1568 and included after revisions and expanding of the apparatus into the Six-Volume Kralice Bible, the climax of the Czech Reformational biblical humanism.

\section{Conclusions}

In line with the heritage of the radical Hussitism, the development of theology in the Unity of the Brethren was much more rapid than in moderate conservative religious currents. The same holds true also for liturgy and pericopal readings. The free choice of pericopes in the first decades was brought back into line by Bishop Lukáš. At the same time, he insisted on a very literal translation from the Vulgate, the most literal one among contemporary Czech translations. In this respect as in other fields, the Unity showed to be the true heir to Czech Hussitism, for literalism was a typical feature of the third redaction of the Old Czech Bible, connected to Prague university circles close to Jan Hus around 1410 [cf. Kyas et al. 1997: 100]. 
Lukášs system, returning to the traditional set of pericopes, was complemented and challenged during the 16th century by an unofficial translation in the Summovník (printed partially possibly around 1570) by Lukáš's successor, Bishop Jan Augusta. He prepared an entirely new system consisting of translations made from the Biblia Tigurina, a Zurich Reformational version. Augusta's translation of pericopes, independent of the Vulgate tradition, was after corrections of other bishops printed as Registrum aneb Zpráva [...]. This undated print, most likely from the span of 1557-1559, displays agreements with the Summovnik, Červenka's Psalter, Blahoslav's New Testament and the Czech Vulgate-based tradition as represented e.g. by Netolický and Melantrich Bibles. As a result, it displays some approximations to the Vulgate in comparison with the Summovnik. It seems that Jan Blahoslav and his colleagues intentionally eliminated extremities of Augusta's translation including some harsh Latinisms, they combined the Vulgate and non-Vulgate tradition and attempted to balance out the literal and loose translation principles. However, the debate in the Unity about pericopes would be continued in the following years. The few pericopes present in Blahoslav's Evanjelia (1571) are identical with pericopes in Štefan's postil (1575). In this postil, some Old Testament verses show a high degree of resemblance to the Registrum whereas a strong inclination to the Vulgate was weakened and many new non-Vulgate readings shared with the Hebrew text were introduced. It is not excluded that the modifications occurring in comparison with the Registrum appeared already in a print of 1563 , yet no preserved copies of this edition prevent us from determining the precise successiveness and from accomplishing reconstruction of textual dependence fully. In this study, due to the amount of material, we limited ourselves intentionally to textual probes only. For a fuller account, a more systematic and elaborate analysis will have to be undertaken in the future.

The pericopal translation in the Summovnik and Registrum both occupy an important place in the history of Czech pericopes since they represent the two Czech earliest preserved translations of parts of the Old Testament with numerous non-Vulgate readings, thus meeting to various degrees the imperative of the hebraica veritas principle, albeit mediated by humanistic Latin. Some New Testament parts of the Registrum, however, may have originated by direct consultation of the Greek versions. In this respect, the Unity proved much more courageous and independent of the preceding tradition than the Czechspeaking Utraquists who basically - at least judging from biblical translations produced massively - remained on the soil of the Vulgate for the whole time of their existence. 


\section{Bibliography}

Old prints and electronic editions

BiblMel2 - Melantrich's Bible of 1556-1557 = Biblí česká [...], Prague, 1556-1557. (Knihopis, No. 1102. Olomouc, Scientific Library, III 32.296.)

BiblNet - Netolický's Bible = Biblí česká [...], Prague, 1549. (Knihopis, No. 1101.

Prague, National Library of the Czech Republic, 54 A 3.)

Blahoslav's Evanjelia - Evanjelia aneb čteni svatá, kteráž slovou pašije [...] [Ivančice], 1571. (Knihopis, No. 2264. Prague, Library of the National Museum of the Czech Republic, 24 B 1.)

Blahoslav's New Testament 1564 - Nový zákon [...] [Ivančice] 1564. (Knihopis, No. 17110. Olomouc, Scientific Library, 32.653.)

Blahoslav's New Testament 1568 - Nový zákon [...] [Ivančice] 1568. (Knihopis, No. 17112a. Prague, National Library of the Czech Republic, 54 S 873.) ČER - Červenka's Psalter $=[$ Červenka, Matěj] [Žaltář svatýho Davida, proroka a krále velikýho] [Olomouc, 1562]. (Knihopis, No. 17555. Olomouc, Scientific Library, 32.676.)

Lukáśss New Testament of 1525 - Nový zákon [...], Mladá Boleslav, 1525. (Knihopis, No. 17097. Prague, Library of the Royal Canonry of Praemonstratensians at Strahov, DR IV 17.)

Münster's translation of 1534-1535 - [...] Hebraica biblia, Latina planeque nova Sebast. Munsteri tralatione [...], Basel, 1534-1535. (Olomouc, Scientific Library, II 261.)

Pagninus - Biblia sacra [...], Coloniae, 1541. (VD16 B 2616. Olomouc, Scientific Library, II 82.)

Reg - Registrum $=[$ Registrum aneb Zpráva [...]], [s. 1., s. a.]. (Knihopis, No. 14768. Prague, National Library of the Czech Republic, 54 B 81.)

$\mathrm{SCR}-$ Textus receptus $=$ edition based on F.H.A. Scrivener's text, quoted according to BibleWorks 9.0.12.718, 2013.

ŠtefPost - Štefan's postil = [Štefan, Ondřej] Výklad řeči Božich [...], [Ivančice], 1575. (Knihopis, No. 15953. Prague, Library of the National Museum of the Czech Republic, 35 C 1.)

Stephanus' Bible of 1556-1557 - Biblia utriusque Testamenti [...], [Geneva], 1556-1557. (GLN 15-16, No. 2021. Brno, Moravian Library, ST4-0050.151Vet; ST4-0050.151,Nov.)

Sum - Summovník = [Augusta, Jan] První dil knih služby slova Božího [Prague, 1570].

(Knihopis, No. 4055. Prague, National Library of the Czech Republic, 54 B 5.)

Tig - Biblia Tigurina $=$ Biblia sacrosancta [...], Tiguri, 1543. (VD16 B 2619. Olomouc, Scientific Library, III 8.) 
$\mathrm{Vg}-$ Vulgata Clementina $=$ Biblia sacra $[\ldots]$, quoted according to BibleWorks 9.0.12.718, 2013.

\section{Secondary literature}

Bat'ová Eliška (2012), Koncepce liturgického roku v hymnologické činnosti Jana Augusty, "Hudební věda", vol. 49, No. 1-2, pp. 33-44.

Bat'ová Eliška (2013), Augustovo "Registrum aneb Zpráva, co se kdy a o čem čísti má” a jeho kontext: nové pohledy, in: O felix Bohemia! Studie k dějinám české reformace, ed. Petr Hlaváček, Univerzita Karlova v Praze - Filosofia, Praha, pp. 195-213.

Bat'ová Eliška (2014), Tisk Blahoslavových "Evanjelii”" v kontextu bratrské liturgie a sakrální rétoriky, in: Amica, Sponsa, Mater. Bible v čase reformace, ed. Ota Halama, Kalich, Praha, pp. 241-260.

Bat'ová Eliška (2016), Prolegomena k interpretaci a dataci nově objeveného Augustova "Summovníku”, "Clavibus unitis”, vol. 5, pp. 1-16.

Bible kralická šestidílná. Kompletni vydání s pưvodními poznámkami (2015), Česká biblická společnost, Praha.

BibleWorks 9.0.12.718 (2013). Fonts: BWGRKL, BWGRKN, and BWGRKI [Greek] PostScript ${ }^{\circledR}$ Type 1 and TrueType fonts. Copyright (C1994-2015 BibleWorks, LLC. All rights reserved. These Biblical Greek and Hebrew fonts are used with permission and are from BibleWorks (www.bibleworks.com). I ask other to comply with displaying and preserving the copyright, if they also distribute any derived publications.

Brown Andrew J. (ed.) (2001), Opera omnia Desiderii Erasmi Roterodami. Recognita et adnotatione critica instructa notisque illustrata. Ordinis sexti tomus secundus, Elsevier, Amsterdam et al.

Bůžek Václav et al. (2010), Společnost českých zemí v raném novověku. Struktury, identity, konflikty, Nakladatelství Lidové noviny, Praha.

Čejka Mirek, Šlosar Dušan, Nechutová Jana (eds.) (1991), Gramatika česká Jana Blahoslava, Masarykova univerzita, Brno.

Dittmann Robert (2012), Dynamika textu Kralické bible v české překladatelské tradici, Refugium Velehrad-Roma, Olomouc.

Dittmann Robert (2016), The Kralice Bible (1579-1593/1594) and Its Later Editions, in: Dittmann Robert, Just Jiř́, Biblical Humanism in Bohemia and Moravia in the 16th Century, Brepols, Turnhout, pp. 249-295.

Dittmann Robert (2017), Textologie perikop Augustova Summovniku, "Studie a texty Evangelické teologické fakulty", vol. 28, No. 1, pp. 57-80.

Dittmann Robert (2018), Slawische Sprachen in der eucharistischen Liturgie in den böhmischen Ländern bis 1621, in: Linguistik als diskursive Schnittstelle zwi- 
schen Recht, Politik und Konflikt, ed. Martin Henzelmann, Dr. Kovač, Hamburg, pp. 103-140.

GLN 15-16= Bibliography of Books Published in the 15th and 16th Centuries in the Cities of Geneva, Lausanne and Neuchâtel, see also http://www.ville-ge.ch/musinfo/bd/bge/gln/ [retrieved on 17th February 2018].

Gordon Bruce, Cameron Euan (2016), Latin Bibles in the Early Modern Period, in: The New Cambridge History of the Bible. Volume 3. From 1450 to 1750, ed. Euan Cameron, Cambridge University Press, Cambridge, pp. 187-216.

Havránek, Bohuslav (1936), Vývoj spisovného jazyka českého, in: Československá vlastivěda. Ǩada II. Spisovný jazyk český a slovenský, ed. Oldřich Hujer, Sfinx Bohumil Janda, Praha, pp. 1-144.

Holeton David R. (1993), The Evolution of Utraquist Liturgy: A Precursor of Western Liturgical Reform, "Religio", vol. 1, No. 2, pp. 155-164.

Holeton David R. (2016), Liturgical Life during the Bohemian Reformation, in: From Hus to Luther. Visual Culture in the Bohemian Reformation (1380-1620), eds. Kateřina Horníčková, Michal Šroněk, Brepols, Turnhout, pp. 121-142.

Just Jiř́i (2007), Biblický humanismus Jana Blahoslava, Praha [unpublished Th.D. dissertation].

Just Jiří (2009), 9. 7. 1609. Rudolfưv Majestát. Světla a stíny náboženské svobody, Praha.

Just Jiří (2016), The Psalter of Matěj Červenka (1562), in: Dittmann Robert, Just Jiří, Biblical Humanism in Bohemia and Moravia in the 16th Century, Brepols, Turnhout, pp. 60-65.

Just Jiří (2017), Summovník Jana Augusty a jeho dochování. Př́spěvek k tématu bratrské knižní kutlury a k možnostem jejího dalšiho výzkumu, "Studie a texty Evangelické teologické fakulty", vol. 28, No. 1, pp. 41-56.

Knihopis $=$ KPS - Databáze Knihopis, available on-line at http://www.knihopis.cz/ [retrieved on 17th February 2018].

Kyas Vladimír et al. (1997), Česká bible v dějinách národního písemnictví, VyšehradKřest’anská akadmie, Praha - ̌̌ím.

Landová Tabita (2012), Lekcionár Jana Augusty a jeho role v bratrském sporu o perikopy, "Listy filologické”, vol. 135, No. 3-4, pp. 333-365.

Landová Tabita (2014), Liturgie Jednoty bratrské (1457-1620), Pavel Mervart, Červený Kostelec.

Macek Josef (2001), Vira a zbožnost jagellonského věku, Argo, Praha.

Šimek Štepán (2019), Jazyk [entry], in: Elektronický slovník staré češtiny, Oddělení vývoje jazyka Ústavu pro jazyk český AV ČR, v. v. i., Praha, available on-line at http://vokabular.ujc.cas.cz/ [retrieved on 5th February 2019]. 
Šmahel František (2001), Husitské Čechy. Struktury, procesy, ideje, Nakladatelství Lidové noviny, Praha.

Šmahel František (2014), The Divided Nation, in: Between Lipany and White Mountain. Essays in Late Medieval and Early Modern Bohemian History in Modern Czech Scholarship, ed. James R. Palmitessa, Brill, Leiden, pp. 63-93.

Šmahel František (2016), Was There a Bohemian Reformation?, in: From Hus to Luther. Visual Culture in the Bohemian Reformation (1380-1620), eds. Kateřina Horníčková, Michal Šroněk, Brepols, Turnhout, pp. 7-16.

Svobodová Andrea, Voleková Kateřina (forthcoming), Nebiblické texty v staročeských prekladech Bible, in: Husitské re-formace. Proměna kulturniho kódu v 15. století, eds. Pavlína Cermanová, Pavel Soukup, Nakladatelství Lidové noviny, Praha.

Válka Josef (2005), Tolerance či koexistence? (K povaze soužití různých náboženských vyznánív českých zemích v 15. až 17. století), in: Husitství na Moravě. Náboženská snášenlivost. Jan Amos Komenský, ed. Josef Válka, Matice moravská, Brno, pp. 237-248.

VD16 = Verzeichnis der im deutschen Sprachbereich erschienenen Drucke des 16. Jahrhunderts. See also https://www.bsb-muenchen.de/sammlungen/historische-drucke/ recherche/vd-16/ [retrieved on 17th February 2018].

Vykypělová Tatána (2013), Wege zum Neutschechischen. Studien zur Geschichte der tschechischen Schriftsprache, Dr. Kovač, Hamburg.

\section{Robert Dittmann \\ Czech Reformational biblical translation: the case of pericopes in the Unity of the Brethren in the 1550s-1570s}

The pericopes in vernacular languages were one of the achievements of the European Reformation. In Bohemian Lands, the pericopes were read in Czech already soon after 1415, namely as a feature of the Hussite movement. Fully Bohemicised liturgy, thus promoting Czech as the first vernacular within the Roman obedience to holy languages, was adopted by the Unity of the Brethren. The development of pericopes within the Unity was dynamic and noteworthy. The study describes and by textual probes illustrates the development of pericopes in the Unity after the reform of Lukas of Prague, which is tightly connected to the most literal Czech biblical translation in the 16th century, published in 1525. In the 1540s, the bishop Jan Augusta attempted at a reform of the pericopal system and in his Summovnik he translated pericopes rather literally from Biblia Tigurina. His translation was modified by other Brethren bishops and printed in 1557-1559. A new revised version came out in 1563 but no copy has survived. In 1571 
Blahoslav's Evanjelia and in 1575 Štefan's Postil were published, both including pericopes. The study explores in detail the mutual textual relations of these prints.

Keywords: Pericopes; Middle Czech; biblical translation; Jan Augusta.

dr Robert Dittmann - absolwent Uniwersytetu Palackiego w Ołomuńcu w Republice Czeskiej (Palacký University in Olomouc, Czech Republic), obecnie wykładowca Uniwersytetu Karola (Charles University) i pracownik badawczy Czeskiej Akademii Nauk w Pradze (Czech Academy of Sciences); zainteresowania naukowe: historia języka czeskiego, przekłady Biblii, onomastyka. 
